J. Clin. Chem. Clin. Biochem.

Vol. 24, 1986, pp. 723-727

(C) 1986 Walter de Gruyter \& Co. Berlin - New York

\title{
Enzyme-Linked Immunosorbent Assay for Apolipoprotein C-I
}

\author{
By W. F. Riesen and E. Sturzenegger \\ Institute for Clinical and Experimental Cancer Research, University of Bern, Tiefenau-Hospital, Bern, Switzer- \\ land
}

(Received March13/June 23, 1986)

Summary: A non-competitive sandwich enzyme-linked immunosorbent assay for apolipoprotein C-I was developed. Sheep antibody to this apolipoprotein C-I, purified by affinity chromatography, was used for coating the wells of a microtiter plate and as a conjugate with alkaline phosphatase. The linear range of the assay was from $80 \mathrm{ng}$ to $15 \mathrm{ng}$. It was sensitive down to $5 \mathrm{ng}$. The intra-assay variation coefficient was $2.8 \%$, and the inter-assay variation coefficient $5.3 \%$. The mean concentration of apolipoprotein C-I was $61 \pm 20 \mathrm{mg} / \mathrm{l}$ in healthy normal males, and $65 \pm 19 \mathrm{mg} / \mathrm{l}$ in females. Apolipoprotein C-I levels were positively correlated with the total cholesterol concentration in both sexes $(p<0.002)$. A significant correlation with triacylglycerol was only observed in males $(p<0.05)$. A significant increase of apolipoprotein $C-I$ was observed in type V hyperlipoproteinaemia, and in the only studied case of type III.

\section{Enzymimmunoassay (ELISA) zur quantitativen Bestimmung von Apolipoprotein C-I}

Zusammenfassung: Es wurde ein nicht kompetitiver enzymimmunometrischer Assay zur Bestimmung von Apolipoprotein C-I entwickelt. Dabei gelangte der gleiche durch Affinitätschromatographie gereinigte Schafanti-Apolipoprotein C-I-Antikörper sowohl zur Beschichtung von Mikrotiterplatten als auch als Enzymkonjugat mit alkalischer Phosphatase zu Anwendung. Der lineare Bereich der Methode lag zwischen 80 und $15 \mathrm{ng}$. Sie war sensitiv bis $5 \mathrm{ng}$. Der Intra-assay-Variationskoeffizient betrug 2,8\%, der Inter-assay-Variationskoeffizient 5,3\%. Bei gesunden männlichen Probanden wurde eine mittlere Apolipoprotein C-I-Konzentration von $61 \pm 20 \mathrm{mg} / 1$ gemessen, bei Frauen eine mittlere Konzentration von $65 \pm 19 \mathrm{mg} / \mathrm{l}$. Die Apolipoprotein C-IKonzentration war positiv korreliert mit der Gesamtcholesterinkonżentration bei beiden Geschlechtern $(p<0,002)$. Mit den Triglyceriden wurde eine signifikante Korrelation nur bei Männern beobachtet $(\mathrm{p}<0,05)$. In hyperlipoproteinämischen Seren wurde eine signifikante Zunahme der Apolipoprotein C-IKonzentration beim Typ V beobachtet und im einzigen untersuchten Fall einer Typ III-Hyperlipoproteinämie.

\section{Introduction}

Knowledge about the concentration of the C-apolipoproteins, which - together with apolipoproteins B and $\mathrm{E}$ - are major apoproteins of triglyceride-rich lipoproteins, is rather limited. Apolipoprotein C-II and apolipoprotein C-III play an important role in the degradation of triglyceride-rich lipoproteins, i. e. chylomicrons and very low density lipoproteins (VLDL): Apolipoprotein C-II is an activator of the enzyme lipoprotein lipase $(1,2)$, known to be respon- sible for the hydrolysis of chylomicrons and VLDL. Deficiency of apolipoprotein C-II has been shown to result in hypertriglyceridaemia (3). Apolipoprotein C-III seems to prevent the hepatic uptake of triglyceride-rich lipoproteins $(4,5)$, and under certain experimental conditions it is capable of inhibiting lipoprotein lipase $(6,7)$. The physiological significance of apolipoprotein C-I is less well understood. The apolipoprotein seems to activate the enzyme lecithin : cholesterol acyl transferase (8), which is responsible for 
cholesterol esterification. This suggests that apolipoprotein $\mathrm{C}$-I, in contrast to the other C-apolipoproteins is of importance in cholesterol metabolism. The importance of the lecithin : cholesterol acyl transferase activation by apolipoprotein C-I in comparison to its activation by apolipoprotein A-I is not yet known. The quantitation of apolipoprotein C-I in dyslipoproteinaemia is expected to provide further insight into the biological role of this apolipoprotein.

The present report describes the development of a non-competitive sandwich enzyme-linked immunosorbent assay (ELISA) for apolipoprotein C-I, and the results obtained in normal and in hyperlipaemic sera.

\section{Materials and Methods}

Lipid analyses

Cholesterol and triglycerides were measured enzymatically in a Technicon AA-II analyser, using reagents from Technicon Instruments Corp. (Tarrytown, N. Y.).

\section{Preparation of lipoprotein density fractions}

Very low density (VLDL), low density (LDL) and high density lipoproteins (HDL) were prepared by a combination of precipitation with $\mathrm{Na}$-phosphotungstate- $\mathrm{MgCl}_{2}$ and ultracentrifugation as previously described by Burstein et al. (9).

Isolation of apolipoprotein and production of antiC-I antibodies

Apolipoprotein C-I was purified from apo VLDL by gel filtration on a column $(2.5 \mathrm{~cm} \times 1.5 \mathrm{~m})$ of Sephacryl S-200 superfine in $6 \mathrm{~mol} / 1$ urea, $0.01 \mathrm{~mol} / 1$ Tris- $\mathrm{HCl}, \mathrm{pH}$ 8.6. The peak containing apolipoprotein $\mathrm{C}-\mathrm{I}$ was further purified by preparative isoelectric focusing on Ultrodex (LKB, Bromma, Sweden) (10). Apolipoprotein C-I was checked for purity by analytical isoelectric focusing, SDS polyacrylamide gel electrophoresis, and double immunodiffusion against anti-apolipoprotein $B$, antiapolipoprotein A-I and anti-apolipoprotein A-II, anti-apolipoprotein C-II/C-III and anti-apolipoprotein $\mathrm{E}$.

Sheep and rabbits were immunized with $1 \mathrm{mg}$ of apolipoprotein C-I in complete Freund's adjuvant and boosted in bi-weekly intervals with the same amount of apolipoprotein C-I in incomplete Freund's adjuvant. Blood was taken after 2 weeks, 4 weeks and 6 weeks. Anti-apolipoprotein C-I antibodies were isolated by immunoadsorption on apolipoprotein C-I-Sepharose, prepared by coupling of apolipoprotein C-I to pre-activated Sepharose $4 \mathrm{~B}$ (Pharmacia, Uppsala): Protein concentration was measured according to the method described by Bensadoun (11).

\section{Quantitation of apolipoprotein C-I by ELISA}

Purified anti-apolipoprotein C-I was conjugated with alkaline phosphatase (Boehringer Mannheim, FRG) according to previous publications $(12,13)$. For coating of the solid phase, purified anti-apolipoprotein C-I at a concentration of $5 \mu \mathrm{g} / 200$ $\mu l$ per well was taken. Coating conditions were $37^{\circ} \mathrm{C}$ for 3 hours, followed by $4{ }^{\circ} \mathrm{C}$ overnight. Subsequently the plates were washed 3 times with phosphate buffered saline-Tween 20 $(0.05 \%), \mathrm{pH} 7.4$. Before use, the plates were saturated by means of $200 \mu \mathrm{l} /$ well of a solution of $1 \%$ bovine serum albumin in phosphate buffered saline, $\mathrm{pH}$ 7.4. Optimal conditions for the ELISA were found to be as follows: $200 \mu \mathrm{l}$ standard or serum in duplicate, diluted 2000 fold with phosphate buffered salineTween, were pipetted into the wells of a precoated microtiter plate. The covered plates were incubated for 2 hours at room temperature and washed 5 times with phosphate buffered saline-Tween. Two hundred microlitres of anti-apolipoprotein CI enzyme conjugate, diluted 30 times with the same buffer, were added per well and the plates were incubated for 5 hours at room temperature. Thereafter, the plates were washed 5 times with phosphate buffered saline-Tween and incubated with $p$-nitrophenylphosphate $(1 \mathrm{~g} / \mathrm{l}), 200 \mu \mathrm{l}$ per well, until absorbance for the highest concentration of the standard was approximately 1.2. The reaction was then stopped by addition of $3 \mathrm{~mol} / 1 \mathrm{NaOH}$ and the developed colour was read at $405 \mathrm{~nm}$ on a Dynatech micro ELISA reader. Results were calculated by logit-log transformation on a programmable HP 97 calculator. Omega $^{\text {TM }}$ Lipid Fraction Control serum (Hyland Diagnostics) was used as a secondary standard, and Roche ${ }^{\mathrm{TM}}$ Lipid Control serum as the quality control.

\section{Statistical analysis}

The significance of the correlation coefficients was calculated by means of the Human Statistic Dynamics Program (HSHStats) on an Apple personal computer.

\section{Results}

\section{Induction of antibodies}

Although apolipoprotein C-I is a rather small protein, antibodies were readily developed with a titer of 100 to $200 \mathrm{mg} / \mathrm{l}$. Upon repeated boosting, however, a decrease in the antibody titer was observed. In addition, not every antibody preparation could be successfully used in the non-competitive ELISA technique. This is thought to be due to epitope saturation by the first (coating) antibody.

Standardization, sensitivity, precision and accuracy of the apolipoprotein C-I ELISA

The standard curves constructed with apolipoprotein C-I, VLDL, LDL, HDL, apolipoprotein A-I, apolipoprotein A-II, apolipoprotein C-II, apolipoprotein C-III and human serum albumin are illustrated in figure 1. The curves prepared with isolated lipoprotein fractions and with apolipoprotein C-I had the same slope. The same holds true for normal human sera, for Omega ${ }^{\mathrm{TM}}$ and for the Roche ${ }^{\mathrm{TM}}$ control serum (not shown). The linear range of the apolipoprotein C-I ELISA was from $80 \mathrm{ng}$ to $15 \mathrm{ng}$, and it was sensitive down to $5 \mathrm{ng}$. The assay was highly specific, as indicated by the low cross-reaction with the various proteins assessed, which never exceeded $1 \%$. The precision of the assay is illustrated in table 1. The average intra-assay coefficient of variation was $3.5 \%$, and the average inter-assay coefficient of variation $6.1 \%$.

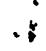




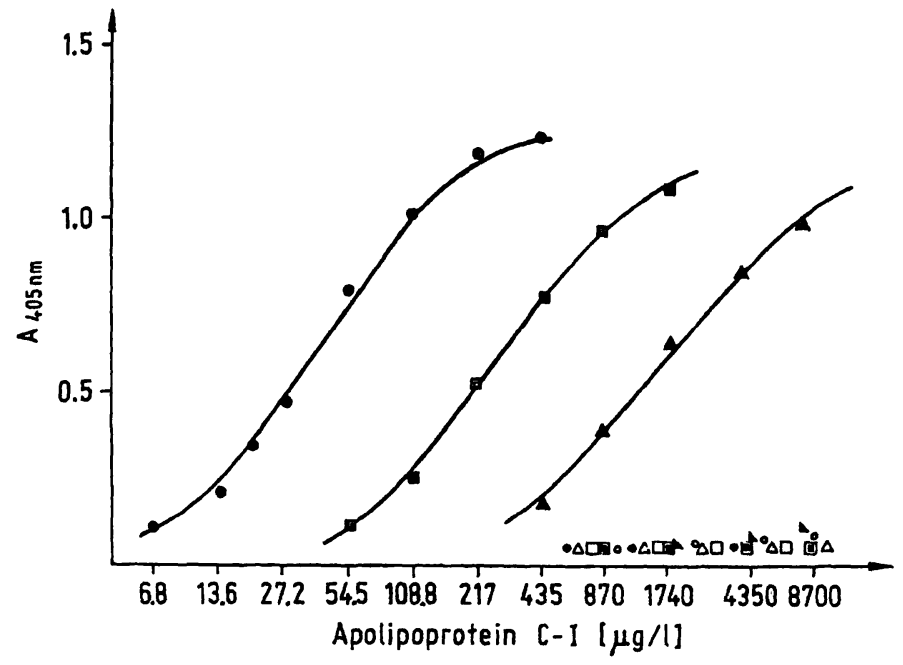

Fig. 1. Standard curves for the apolipoprotein C-I ELISA

(๑) apolipoprotein C-I

(*) apolipoprotein C-II

(o) apolipoprotein C-III

(a) VLDI

(A) $\mathrm{HDL}$

(ه) LDL

() apolipoprotein A-I

(D) apolipoprotein A-II

(回) human serum albumin

Tab. 1 Precision of the apolipoprotein C-I ELISA

\begin{tabular}{|c|c|c|}
\hline $\begin{array}{l}\text { Apolipoprotein } \\
\text { C-I } \\
(\mathrm{g} / \mathrm{l})\end{array}$ & $\begin{array}{l}\text { Intra-assay CV } \\
(\%) \\
(n=10)\end{array}$ & $\begin{array}{l}\text { Inter-assay CV } \\
(\%) \\
(n=10)\end{array}$ \\
\hline $\begin{array}{l}0.107 \\
0.051\end{array}$ & $\begin{array}{l}2.8 \\
4.1\end{array}$ & $\begin{array}{l}5.3 \\
6.8\end{array}$ \\
\hline
\end{tabular}

The recoveries obtained by the ELISA technique after addition of isolated apolipoprotein C-I in known concentrations to a normal serum are given in table 2. The recoveries corresponded to the precision of the assay, indicating a satisfactory accuracy of the tests.

No difference was obtained when the sera were delipidated with tetra-methyl-urea $(1+1 \mathrm{v} / \mathrm{v})$ prior to analysis, suggesting that the apolipoprotein C-I epitopes recognized by our antibody are fully exposed in native lipoproteins.

The influence of storage on the concentration of apolipoprotein C-I was stưdièd by assessing the apoli- poprotein C-I levels in 3 different groups of sera: sera stored for 2 to 3 months at $-20^{\circ} \mathrm{C}(\mathrm{n}=14)$, sera stored for up to 4 years with repeated freezing and thawing $(\mathrm{N}=29)$ and fresh sera. All groups of sera had similar levels of cholesterol and triglycerides. The mean apolipoprotein C-I value did not significantly differ between the 3 groups of sera, indicating that storage at $-20^{\circ} \mathrm{C}$ even over several years has no significant influence on the concentration of apolipoprotein $\mathrm{C}-\mathrm{I}$ in our assay.

\section{Apolipoprotein C-I levels in normal blood donors}

Table 3 summarizes the serum concentration of apolipoprotein C-I in normal males and females of similar age (males: $55 \pm 13$, females: $52 \pm 15$ years old). The difference between both groups was statistically not significant.

Tab. 3. Concentration of apolipoprotein C-I, total serum cholesterol and triglycerides in apparently healthy males and females

\begin{tabular}{lllll}
\hline Sex & $\mathbf{n}$ & $\begin{array}{l}\text { Apolipo- } \\
\text { protein } \\
\text { C-I }(\mathrm{g} / \mathrm{l})\end{array}$ & $\begin{array}{l}\text { Total } \\
\text { cholesterol } \\
(\mathrm{mmol} / \mathrm{l})\end{array}$ & $\begin{array}{l}\text { Triglycerides } \\
(\mathrm{mmol} / \mathrm{l})\end{array}$ \\
\hline Male & 38 & $0.061 \pm 0.020$ & $5.2 \pm 0.8$ & $1.5 \pm 0.4$ \\
Female & 32 & $0.065 \pm 0.019$ & $5.4 \pm 0.6$ & $1.5 \pm 0.3$ \\
\hline
\end{tabular}

Apolipoprotein C-I levels correlated significantly with the total cholesterol concentration in both sexes (males: $\mathrm{r}=0.45, \mathrm{p}<0.001$; females: $\mathrm{r}=0.47$, $\mathrm{p}<$ 0.002 ). In contrast, the correlation between apolipoprotein $\mathrm{C}-\mathrm{I}$ and the triglycerides only reached significance in males $(r=0.35, p<0.05)$. In females these two parameters were not significantly correlated $(r=0.23, p=0.21)$.

The quantitation of apolipoprotein C-I in the different lipoprotein density fractions indicates that this apolipoprotein predominates in the VLDL class. Fifteen per cent of the total protein content of this fraction consisted of apolipoprotein C-I. In LDL, apolipoprotein C-I made up $0.1 \%$ of the protein part, in HDL $1.7 \%$.

Tab. 2. Accuracy of the ELISA for apolipoprotein C-I

\begin{tabular}{llllr}
\hline $\begin{array}{l}\text { Apolipoprotein C-I } \\
\text { in serum }(\mathrm{g} / \mathrm{l})\end{array}$ & $\begin{array}{l}\text { Apolipoprotein C-I } \\
\text { added }(\mathrm{g} / \mathrm{l})\end{array}$ & $\begin{array}{l}\text { Apolipoprotein C-I } \\
\text { expected }(\mathrm{g} / \mathrm{l})\end{array}$ & $\begin{array}{l}\text { Apolipoprotein C-I } \\
\text { found }(\mathrm{g} / \mathrm{l})\end{array}$ & $\begin{array}{r}\text { Recovered (\%) } \\
\hline 0.061\end{array}$ \\
\hline 0.061 & 0.054 & 0.115 & 0.117 & 102 \\
0.061 & 0.111 & 0.172 & 0.163 & 95 \\
\hline
\end{tabular}


Tab. 4. Apolipoprotein C-I and lipid levels in patients with different types of hyperlipoproteinaemia

\begin{tabular}{|c|c|c|c|c|c|c|}
\hline \multirow[t]{2}{*}{ Type } & \multirow[t]{2}{*}{$\mathbf{n}$} & \multirow{2}{*}{$\begin{array}{l}\text { Apolipoprotein } \\
\text { C-I }(\mathrm{g} / \mathrm{l})\end{array}$} & \multirow{2}{*}{$\begin{array}{l}\text { Triglycerides } \\
(\mathrm{mmol} / \mathrm{l})\end{array}$} & \multirow{2}{*}{$\begin{array}{l}\text { Cholesterol } \\
(\mathrm{mmol} / \mathrm{l})\end{array}$} & \multicolumn{2}{|l|}{ Correlation $\mathbf{r}$} \\
\hline & & & & & $\begin{array}{l}\text { Apolipoprotein C-I/ } \\
\text { Triglycerides }\end{array}$ & $\begin{array}{l}\text { Apolipoprotein C-I/ } \\
\text { Cholesterol }\end{array}$ \\
\hline I & 5 & $0.061 \pm 0.041$ & $12.5 \pm 1.7$ & $4.5 \pm 0.9$ & 0.74 & 0.86 \\
\hline II a & 31 & $0.072 \pm 0.022$ & $1.6 \pm 0.3$ & $8.3 \pm 1.6$ & -0.06 & -0.07 \\
\hline II b & 30 & $0.069 \pm 0.029$ & $2.7 \pm 0.8$ & $7.7 \pm 0.9$ & 0.09 & $0.39 *$ ) \\
\hline III & 1 & 0.148 & 11.6 & 18.0 & - & - \\
\hline IV & 24 & $0.086 \pm 0.039$ & $5.4 \pm 2.5$ & $6.6 \pm 1.3$ & 0.23 & $\left.0.50^{* *}\right)$ \\
\hline V & 23 & $0.123 \pm 0.062$ & $17.5 \pm 10.9$ & $12.1 \pm 5.4$ & 0.00 & $0.39 *)$ \\
\hline
\end{tabular}

*) $\mathrm{p}<0.05$

**) $\mathrm{p}<0.01$

Apolipoprotein C-I levels in hyperlipoproteinaemia

The level of apolipoprotein C-I in the different types of hyperlipoproteinaemia and its correlation to the concentration of total serum cholesterol and triglycerides are summarized in the table 4 . A significant increase in the mean apolipoprotein C-I concentration was observed in type $\mathrm{V}$ hyperlipoproteinaemia $(p<0.05)$ and in the serum of the only patient with type III hyperlipoproteinaemia (apolipoprotein C-I level: $0.148 \mathrm{~g} / \mathrm{l})$. In the other types, the mean apolipoprotein C-I concentration was comparable to values observed in normal blood donors. A significant correlation was found between apolipoprotein C-I and total cholesterol in all types, with the exception of type II a hyperlipoproteinaemia, while no significant correlation was observed with the triglycerides.

\section{Discussion}

This report describes the development of a sandwichELISA for the quantitative determination of apolipoprotein C-I in serum and in isolated lipoprotein density fractions. The results obtained with this assay show good precision, high sensitivity and appropriate accuracy. So far, the quantitative determination of apolipoprotein C-I by immunoassay has been reported only once (14), using electroimmunodiffusion. Our data are in good agreement with these values.

The ELISA offers some advantages over electroimmunodiffusion: it is more sensitive and it does not depend on a standard with the same migration properties as the serum. This may be particularly crucial with very large molecules like VLDL, which are known to transport the major part of the Capolipoproteins. The standard curves obtained with isolated apolipoprotein C-I, native serum and isolated lipoprotein density classes were found to be parallel, indicating immunological identity of apolipoprotein
C-I in each lipoprotein class. Delipidation of the serum did not increase the amount of apolipoprotein C-I as measured by our polyclonal antibody. This indicates that the apolipoprotein C-I epitopes are fully exposed to the antibodies in this assay system.

Lipid and lipoprotein levels are known to be influenced by sex hormones (15). Differences between males and females have been noted for the level of most apolipoproteins by many authors, i. e. apolipoprotein B (16), apolipoprotein A-I $(17-21)$, apolipoprotein A-II $(18,20)$, for apolipoprotein C-III (22) and for apolipoprotein E (23). So far no data about the level of apolipoprotein $C=I$ in males and females are known. Our results indicate that apolipoprotein C-I differs from most other lipoproteins, in that its serum level shows remarkably similar values in both sexes.

Our finding was that $15 \%$ of the protein part of VLDL consists of apolipoprotein C-I. According to Kashyap et al., apolipoprotein C-III makes up $18 \%$ of apo VLDL (24). This would leave about $12 \%$ for apolipoprotein C-II if one assumes that the Capolipoproteins contribute about $45 \%$ of the VLDLproteins. This seems to be a reasonable distribution. Since the C-apolipoproteins constitute the major protein part of VLDL, one would expect a close correlation between the level of the triglycerides, which essentially are transported within this lipoprotein class, and the concentration of the C-apolipoproteins. Indeed, such a correlation was observed for apolipoprotein C-IIII $(22,24,25)$. Surprisingly, a significant correlation was found between apolipoprotein C-I and total cholesterol in both sexes, while the correlation between apolipoprotein C-I and triglycerides reached the level of significance only in normal men. This might be due to the fact that triglycerides are transported apart from VLDL in chylomicrons which do not contain very much protein. Therefore apolipoprotein C-I levels were correlated to VLDL-cholesterol and -triglycerides. However, no substantial in- 
crease of the correlation coefficients between apolipoprotein C-I and VLDL-triglycerides was observed in either type IV nor type V hyperlipoproteinaemia, while the correlation coefficient between apolipoprotein C-I and VLDL-cholesterol was slightly increased as compared to total cholesterol.

In contrast to apolipoprotein C-III, which seems to be increased in all types of hyperlipoproteinaemia $(22,25)$, a significant increase of apolipoprotein C-I was only observed in type $\mathrm{V}$ hyperlipoproteinaemia. The observed correlation between apolipoprotein C$\mathrm{I}$ and total cholesterol was present in all types of hyperlipoproteinaemia, with the exception of pure hypercholesterolaemia (type II a). This is rather unexpected, since apolipoprotein C-I levels were only increased in type $\mathrm{V}$ hyperlipoproteinaemia. At present we have no explanation for this observation. The finding of an association between apolipoprotein C$\mathrm{I}$ and the total serum cholesterol concentration may be of interest in view of the ability of apolipoprotein
C-I to activate lecithin: cholesterol acyl transferase (8), which mediates the formation of cholesterol esters from unesterified cholesterol and phosphatidyl choline (26). Our data might therefore suggest that apolipoprotein C-I plays a much more important role in lipoprotein metabolism than previously thought. The observation of a rather indifferent level of apolipoprotein C-I in the different types of hyperlipoproteinaemia (with the exception of type V), however, is not in favour of such a hypothesis. Further studies on the concentration of apolipoprotein C-I and on its distribution within the various density classes of lipoproteins in different types of diseases will be needed in order to get more insight into the physiological significance of apolipoprotein C-I.

\section{Acknowledgement}

The authors wish to thank Miss Elisabeth Ischi for excellent technical assistance. This work was supported by a grant from the Swiss National Science Foundation.

\section{References}

1. LaRosa, J. C., Levy, R. I., Herbert, P. N., Lux, S. E. \& Fredrickson, D. S. (1970) Biochem. Biophys. Res. Commun. 41, 57-62.

2. Havel, R. J., Fielding, C. J., Olivecrona, T., Shore, V. G., Fielding, P. E. \& Egelrud, T. (1973) Biochemistry 12, 18281833.

3. Breckenridge, W. C., Little, J. A., Steiner, G., Chow, A. \& Poabst, M. (1978), New Engl. J. Med. 298, 1265-1273.

4. Shelbourne, F., Hanks, J., Meyers, W. \& Quarfordt, S. (1980) J. Clin. Invest. 65, 652-658.

5. Windler, E., Chao, Y. \& Ḧavel, R. J. (1980) J. Biol. Chem. 255, 8303-8307.

6. Brown, W. V. \& Baginsky, M. L. (1972) Biochem. Biophys. Res. Comm. 46, 375-382.

7. Krauss, R. M., Herbert, P. N., Levy, R. I. \& Fredrickson, D. S. (1973) Circulation Res. 33, 403-411.

8. Soutar, A. K., Garner, C. W., Baker, H. N., Sparrow, J. T., Jackson, R. L., Gotto, A. M. \& Smith, L. C. (1975) Biochemistry (USA) 14, 3057-3064.

9. Burstein, M., Scholnik, H. R. \& Morfin, R. (1970) J. Lipid Res. 11, 583-595.

10. Marcel, Y. L., Bergseth, M. \& Nestruck, A. C. (1979) Biochim. Biophys. Acta 573, 175-183.

11. Bensadoun, A. \& Weinstein, D. (1976) Anal. Biochem. 70, $241-250$.

12. Engvall, E. \& Perlmann, P. (1971) Immunochemistry 8 , $871-874$.

13. Sullivan, M. J., Gnemmi, E., Morris, E., Chieregatti, G., Simmons, M., Simmonds, A. D., Bridges, J. W. \& Marks, V. (1978) FEBS Letters 95, 311-315.
14. Curry, M. D., McConathy, W. J., Fesmire, J. D. \& Alaupovic, P. (1981) Clin. Chem. 27, 543-548.

15. The Lipid Research Clinics Program Epidemiology Committee (1979) Circulation 60, 427-439.

16. Curry, M. D., Gustafson, A., Alaupovic, P. \& McConathy, W. J. (1978) Clin. Chem. 24, 280-286.

17. Karlin, J. B., John, D. J., Starr, J. I., Scann, A. M. \& Rubenstein, A. A. (1976), J. Lipid Res. 17, 30-37.

18. Assmann, G., Smootz, E., Adler, K., Capurso, A. \& Oette, K. (1977) J. Clin. Invest. 59, 565-575.

19. Cheung, M. C. \& Albers, J. J. (1977) J. Clin. Invest. 60, 43-50.

20. Riesen, W. F., Mordasini, R. C. \& Middelhoff, G. W. (1978) FEBS Letters 91, 35-39.

21. Mao, S. J. T., Miller, J. P., Gotto, A. M. \& Sparrow, J. T. (1980) J. Biol. Chem. 255, 3448-3453.

22. Riesen, W. F. \& Sturzenegger, E. (1986) Ann. Clin. Biochem. in press.

23. Havel, R. J., Kotite, L., Vigne, J.-L., Kane, J. P., Tun, P., Phillips, N. \& Chen, G. C. (1980) J. Clin. Invest. 66, 1351 1362.

24. Kashyạp, M. L., Srivastava, L. S., Hynd, B. A., Gartside, P. S. \& Perisutti, G. (1981) J. Lipid Res. 22, 800-810.

25. Bury, J. \& Rosseneu, M. (1985) J. Clin. Chem. Clin. Biochem. $23,63-68$.

26. Glomset, J. A. (1962) Biochim. Biophys. Acta 65, 128135.

Prof. Dr. W. F. Riesen Institute for Clin.-Exp.

Cancer Research

University of Bern

Tiefenauspital

CH-3004 Bern 


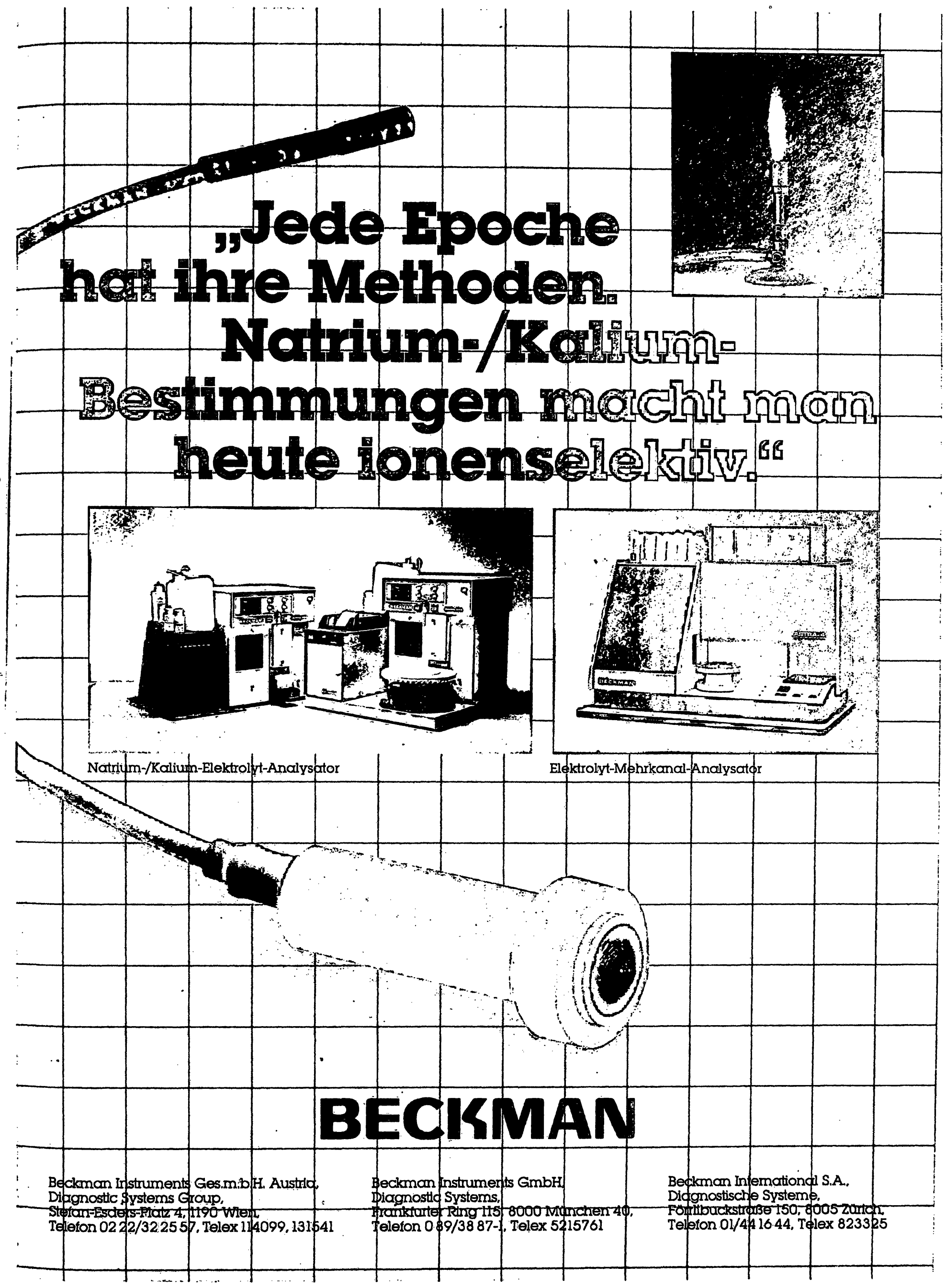




\section{Neopterin-RIAcid}

\section{Neopterin is formed by macrophages upon stimulation with interferons in a side reaction of tetrahydrobiopterin synthesis}
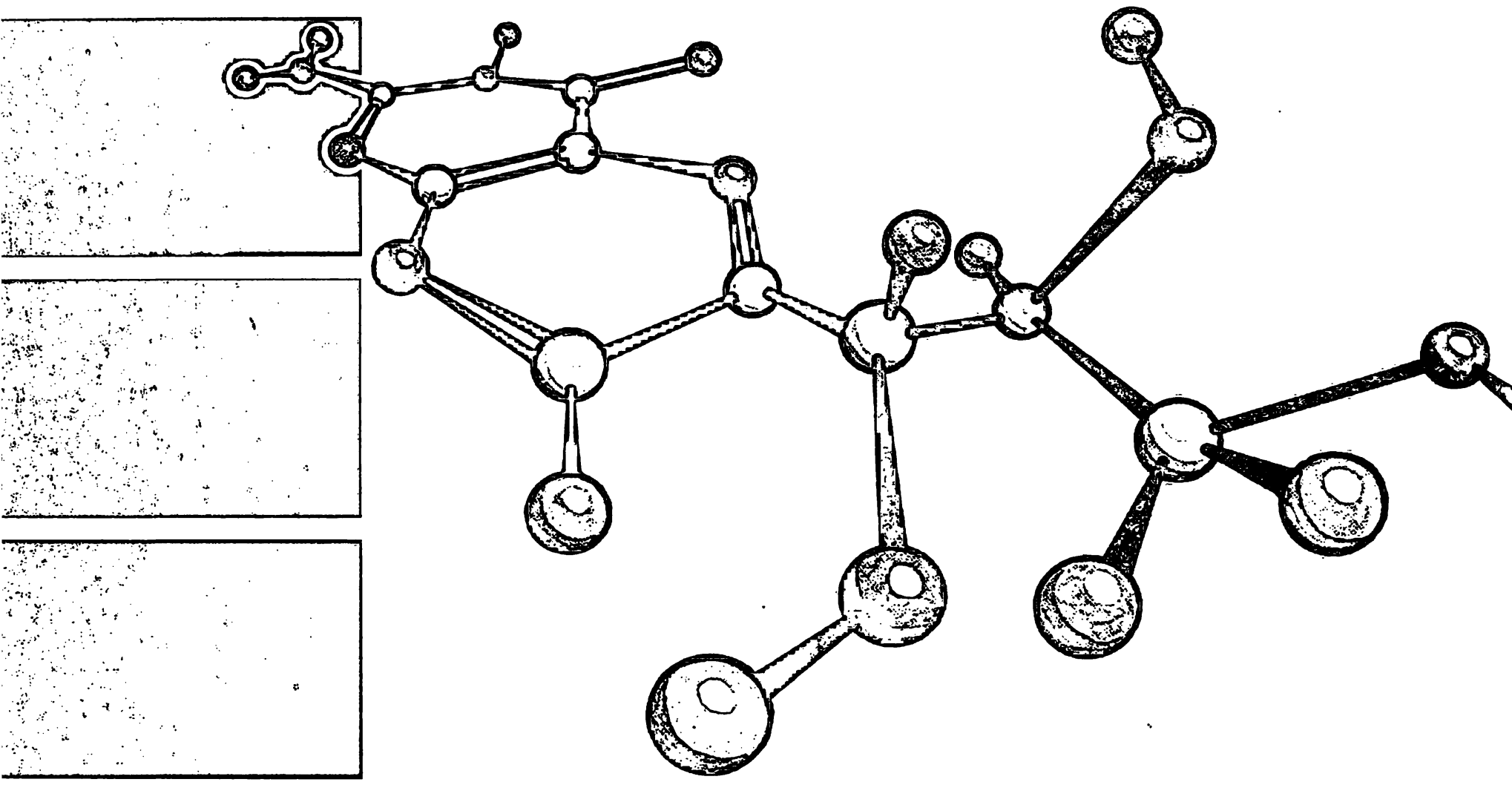

Neopterin levels in serum and urine are elevated in patients with

$\checkmark$ transplant rejection (in kidney, heart, liver, pancreas, bone marrow transplants)

$\checkmark$ various tumours (ovarian cancer, leukemias, lymphomas)

$\checkmark$ viral and other diseases (Epstein-Barr virus,

cytomegalovirus, hepatitis, AIDS, malaria,and septic complications)

Neopterin-RIAcid ${ }^{\circledR}$ is an easy to handle radioimmunoassay

$\checkmark$ double antibody technique

$\checkmark$ 125iodine tracer

- 3 pipetting steps only

- incubation 2 hours at room temperature

\section{... for your research from HENNING BERLIN}

